Věda a perspektivy № 5(5) 2021

ISSN 2695-1584 (Print)

ISSN 2695-1592 (Onfine)

https://doi.org/10.52058/2695-1592-2021-5(5)-57-61

\title{
Andrii Sysoev
}

Graduate student, Economy and Finance of enterprise department,

Kyiv National University of Trade and Economics, Kyiv, Ukraine, e-mail: sysoevandrey@gmail.com, https://orcid.org/0000-0001-8657-0925

\section{THE IMPROVEMENT OF FINANCIAL CONTROLLING'S INFORMATION SUPPORT OF THE OPERATING ACTIVITIES OF TRADE ENTERPRISE}

\begin{abstract}
The article pays attention on requirements for information support for controlling the operating activities of trade enterprises: significance, completeness, reliability, timeliness, clarity, relevance, comparability and efficiency. Also, it contains the proposals of improvement the financial controlling's information support of the operating activities of trade enterprise: reduce and avoid the "gap" between the complexity of financial accounting and the level of qualification of managers; the ways of correct choice making of accounting unit (physical, national and foreign currencies); the system of key controlling indicators (in contains the groups of the main indicators from six the most important fields of enterprise business activity).
\end{abstract}

Keywords: controlling, informational support, activity of enterprise,

Introduction. Information support is very important area in any business activity. Even, the government creates the main it's rules. Every company try to create the own information support system to manage it's business. The most important information flows of trade enterprises are related with it's operating activity. In the process of it's controlling discovers the requirements to improve it so deep as it's possible.

Creation and improvement the information system of enterprise's controlling is actual for all the enterprises that cares about resistance of crisis and rising it's own effectiveness. It have to be done just in time, taken the optimal resources spending and to be able to meet lot of others requirements.

Importance of the topic mention's lot of scientists, including Perevozova I.[1], Veretin L.S.[2], Larry Walther[3], Blank I.A.[4], Helmut Siller [5], ets. It let to pay attention to the most important areas of enterprise activity and make the adequate conclusions and decisions.

Informational system of each company have meet special quite deep

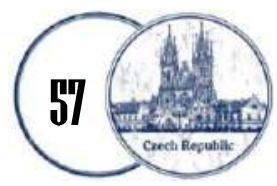


requirements of its unique business activity. It have to be adopted to mentality and culture of manager's behavior. It have to be created special improvements for trade companies. This is the main required field of scientific investigation.

The objective of research is to investigate the ways of improvement the informational support of trading company operational activity.

Results and Discussion. Decisions making process in business always contains the "unknowns". Larry Walther mentions that business managers must rely on systematic monitoring tools to maintain awareness of where the business is headed. Managerial accounting provides these monitoring tools and establishes a logical basis for making adjustments to business operations [3]. We agree with him. But, controlling system have to make the main requirements for it's accounting. The task of controlling is to establish an information system that would display all the necessary information for conscious management decisions. The information must arrive just in time and reflect a general state of affairs, to display the necessary details and have no overloading the user with unnecessary facts. That is why it is worth mentioning the identified by Blank I.O. requirements for information support of financial management [4], which are also relevant for controlling the operating activities of trade enterprises: significance, completeness, reliability, timeliness, clarity, relevance, comparability and efficiency.

In many companies, managers do not use or almost do not use financial accounting data in full. Such cases are the result of a significant "gap" between the complexity of financial accounting and the level of qualification of managers. To remedy this situation, it is necessary to make efforts and resources to train managers, or to simplify the composition, form of managerial accounting and reporting. Understanding is better and more useful than "memorizing information". Therefore, at the first stage it is proposed to simplify the information support of managers. Then, it's quality have to be improved together with improving the skills of managers.

So, the tempus quality of implementation system of managerial accounting and reporting depends on temps of TOP-manager's education.

Particular attention should be paid to the issue of the accounting unit for convenient controlling of the enterprise's activities. To have it's clear understanding of the scope of activities it is the best to keep accounting of inventory in physical units. It will completely eliminate the problems caused by inflation and currency risks.

For companies with international activities - we recommend to keep accounting in several currencies at the same time to more accurately reflect the effectiveness of business operations. After all, in the process of conducting management accounting in foreign currency, the assessment the efficiency of business processes carried out in foreign country in it's national currency will be distorted by exchange rate fluctuations. That is why the assessment of the efficiency of business processes of the

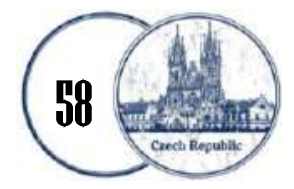


enterprise should be calculated in the currency of the country of its implementation. The assessment of the effectiveness of investments should be made in the currency of the invested funds. This approach will allow to find more reserves to increase the efficiency of enterprise's activities.

It isn't possible and it doesn't worth to use all the complex of possible indicators in the process of controlling enterprise's business activity. Therefore, it is necessary to identify the most important (key) indicators that will comprehensively reflect the level of achievement of goals.

To manage the activities of the enterprise within the controlling system of TOPmanagement, it is proposed to display the key indicators of controlling in terms of four groups: cash flow, profit and loss statement, balance sheet, statistics, ratios, tasks (Fig.1.). For each of the groups, the planned values, actual data and deviations should be displayed (in the current period it is also possible to display the forecast fact and the forecast deviation).

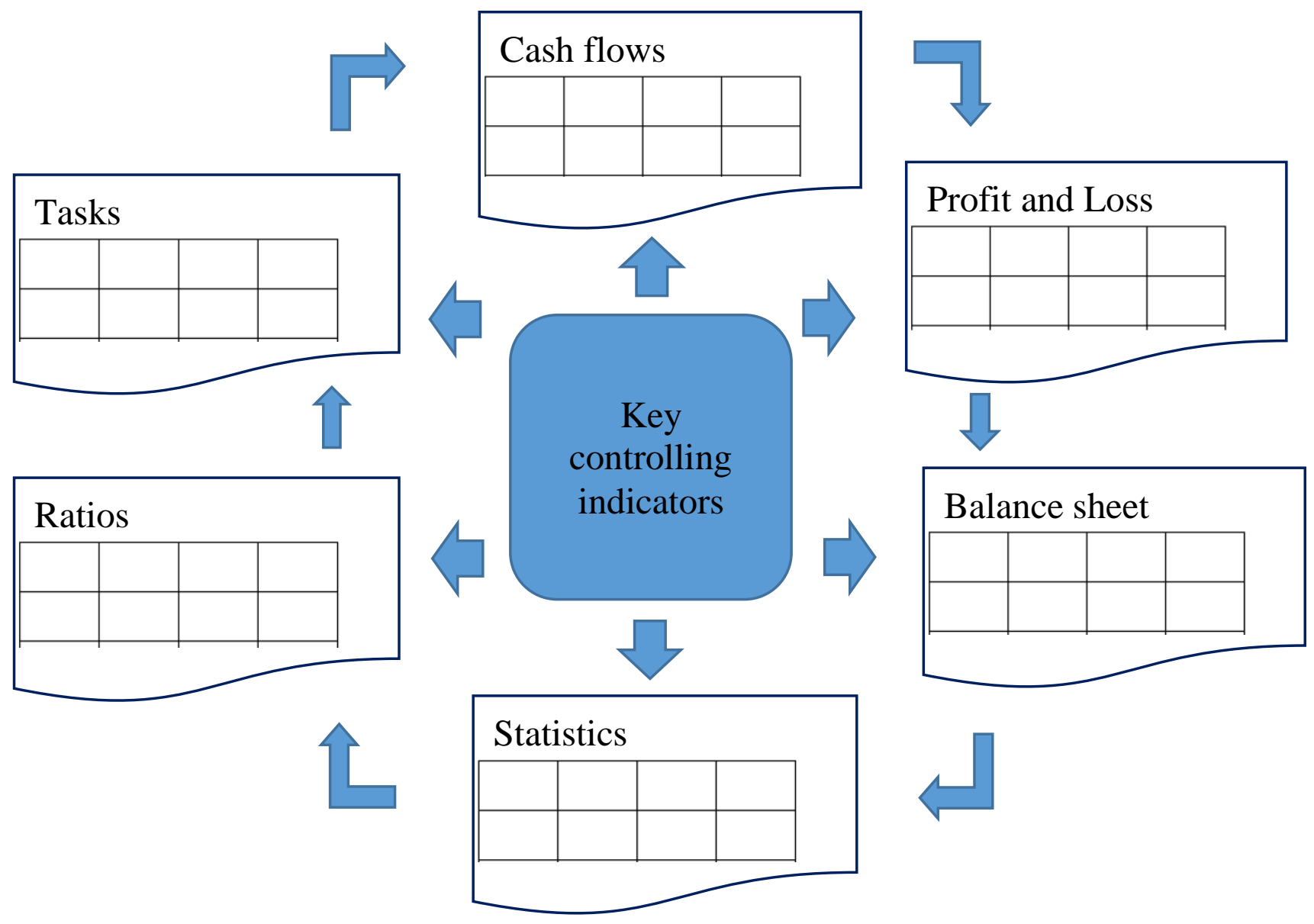

Source: developed and proposed by the author

Fig. 1. Groups of key controlling indicators

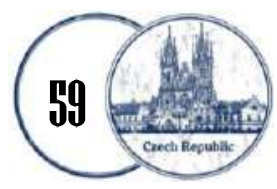


Cash flow is essentially the most important object of management. Therefore, the departments that manage cash flows, as a rule, are under the direct authority of the head of the enterprise. The head of the enterprise cannot and should not control all cash flows in deep details. At the same time, he must clearly understand the general payment situation and the state of management of the most important cash flows. Each business can have own level of importance for each type of cash flows. For example, companies whose activities are completely dependent on the producers of exclusive goods, one of the critical will be the timely and full fulfillment of financial obligations to such counterparties. Businesses, that have an extremely high dependence of profitability on some specific groups of staff, have extremely important cash flows related with salary payments for them.

However, it is incorrect to manage the finances of the enterprise with the help of cash flow data only. In some case it can lead to losses and further bankruptcy of the enterprise. Therefore, the profit and loss statement is important in the process of enterprise's management. It contains important data on the efficiency and effectiveness of the enterprise. After all, it reflects the total amount of costs incurred for the sale of goods of the enterprise. It have to be chosen the most important indicators from this report that characterizes results of activity of the investigated enterprise.

The balance sheet characterizes the property status of the enterprise. More precisely, the composition of assets and sources of it's financing. With the help of this document you can see not only the volume and direction of investment, but also the level of achievement of certain strategic goals. Therefore, the key indicators of the balance sheet of the enterprise must be reflected in the reporting form of controlling. For different companies, the choice may fall on slightly different indicators depending on the characteristics of business activities of enterprises.

To manage the enterprise's business activity the managers have deep need in the additional statistical information, which is not included in the enterprise's financial statements. For example, sales in physical units, number of staff, retail and total area of the supermarket chain, etc. Therefore, it is proposed to use in the process of controlling the activities of the enterprise a group of statistical indicators, that are not reflected in the financial statements of the enterprise.

Absolute values of indicators, that describes different areas of the enterprise are not enough for effective enterprise management. It is important to have ratio analysis, which gives a qualitative description of the enterprise development state. Therefore, we propose usage the ratios in one of separated groups of key controlling indicators. The most important indicators should be selected there, that comprehensively reflect the effectiveness of business, identify the problem areas, defines reserves to improve the efficiency of the enterprise.

Also, we propose apply the sixth group of controlling indicators to reflect the

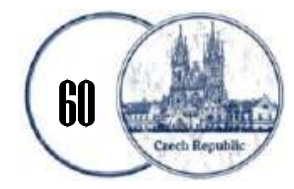


status of tasks execution. The state of fulfillment of the tasks is a prerequisite for improvement of the values of financial and statistical indicators. Understanding the status of strategically important tasks is extremely important to take measures of timely it's improvement and achievement the goals. For example, attending exhibitions, seminars and conferences, the state of opening new branches, automation of a business process, etc.

The proposed groups of key controlling indicators have to describe the general situation of operational activity management and pay attention to the appearance of problem sites of trade enterprise.

Conclusions. Controlling the operational activity of trade enterprise needs to be supported with correctly formulated information support. It have meet all the main requirements and be ready for improvement according to unique conditions of company: it have meet perception of managers, specific drivers of enterprise's business and reflect all the main sides of business activity in one site. We propose usage in the process of operational activity controlling the indicators of six fields: cash flow, profit and loss statement, balance sheet, statistics, ratios, tasks.

\section{References:}

1. Perevozova, I. (2018) Application of the latest information technologies in the control system as a metasystem of management by an industrial enterprise. Theoretical and Practical Aspects of Economics and Intellectual Property Retrieved from: http://tpa.pstu.edu/article/view/147180 [In Ukrainian].

2. Veretin L.S. (2015) Information support as one of the preconditions management of productivity company. Efficient economy, 4, Retrieved from: http://www.economy.nayka.com.ua/?op=1\&z=4469 [In Ukrainian].

3. Larry Walther Planning, Directing, And Controlling. Retrieved from: https://www.principlesofaccounting.com/chapter-17/planning/

4. Blank, I.A. (2011). Fundamentals of Financial Management: Part 1. - K.: Nika-centr, Elga. [in Russian].

5. Helmut Siller (2019) Basics for digital reporting. Controlling-Journal. Retrieved from: https://www.controllingportal.de/Controlling-Journal/Archiv/ [in Deutch]. 